\title{
Development of the Agricultural Biogas Market in Poland - Production Volume, Feedstocks, Activities and Behaviours of Farmers ${ }^{2}$
}

\begin{abstract}
The activity and efficiency of agricultural biogas plants are important issues in the field of low-emission development in rural areas and in agribusiness. The essence of the problems concerns mainly sustainable waste management in agricultural production. The main purpose of this study is to analyze the volume of agricultural biogas production in Poland and the structure of consumption of raw materials used for production of agricultural biogas. The analyses were carried out in the period of 2011-2017. The paper also presents results of empirical research on the agricultural practices as part of the subject area of the development of the agricultural biogas market in Poland. The aim of the questionnaire surveys of agricultural holdings was to obtain information on the use of the biomass from field crops and grasslands for energy purposes and the interest in the development of agricultural production towards the cultivation of energy crops. The results of the analyses were presented in the spatial arrangement of research.
\end{abstract}

Key words: low carbon agriculture, agricultural biogas plants, Poland

JEL Classification: Q12, Q13, Q42

\section{Introduction}

Agricultural activity, understood as purposeful cultivation of plants and livestock breeding for the purpose of obtaining certain goods for satisfying the social needs, has been subjected to major changes in Poland in recent years. An important direction of changes is an increase in the supply of goods from the agricultural sector for the use for energy purposes. This applies both to changes in the structure of agricultural production (including an increase in the area of rapeseed crops and energy crop plantations) as well as the use of waste from the plant and animal production for energy purposes. Agriculture and rural areas in Poland have a very large potential for the development of the bioenergy sector. An important direction of the development of the market of renewable energy sources in rural areas is the production of energy in agricultural biogas plants (Ingrao et al., 2019; Piwowar, Dzikuć, Adamczyk, 2016; Appel, Ostermeyer-Wiethaup, Balmann, 2016; Bała, 2017; Kozłowski et al., 2018; Czekała, 2018). European Union's efforts aimed at increasing the share of the energy produced from renewable energy sources are conducive to this (Directive 2009/28/EC). A relatively quick increase in the production of energy obtained from agricultural biogas plants has been recorded in recent years in Visegrad Group countries (Chodkowska-Miszczuk, Kulla, Novotný, 2017; Piwowar, Olszańska, Režný,

${ }^{1}$ Dr hab. inż., prof. UE, ul. Komandorska 118/120, 53-345 Wrocław, e-mail: arkadiusz.piwowar@ue.wroc.pl, https://orcid.org/0000-0001-5676-9431

${ }^{2}$ Article funded by the National Science Centre from the funds for science within research project in the field of basic research - Sonata No. 2016/21/D/HS4/00087, entitled "The state and prospects of the development of lowcarbon agriculture in Poland and the behaviour of agricultural producers." 
2017). The development of the biogas market is particularly important in countries with a relatively low energy self-sufficiency and security. The necessity of replacing fossil fuels with renewable raw materials is also important in the investigated problem area. The production of biogas in the European Union is the largest in Germany and Italy (Torrijos, 2016; D'Imporzano et al., 2018; Scarlat, Dallemand, Fahl, 2018). The largest share in the structure of the energy obtained from renewable energy sources in the European Union is in Germany (over 20\% share) (Majewski, Sulewski, Wąs, 2016).

Agricultural biogas plant is an element of technical infrastructure more and more frequently met in rural areas in Poland. From the technical point of view, an agricultural biogas plant is an installation for the purposeful production of biogas, where bioproducts from agriculture as well as forest biomass and waste from the food industry are used as the substrate for the production. It is important from the economic and ecological point of view that the substrates for the production of agricultural biogas include mainly residues from crop production, livestock manure as well as residues or by-products from agricultural and food processing. Thus, the biogas obtained in agricultural biogas plants in the process of anaerobic digestion of biomass belongs to renewable energy sources. The use of the residues from the agricultural and food industry as well as by-products of agriculture in agricultural biogas plants contributes significantly to the protection of the natural environment and plays an important role in it (Zain \& Mohamed, 2018; Kuziemska et al., 2014). As mentioned earlier, different substrates can be used in the production process. Depending on the parameters of the substrate (dry matter content, rate of decomposition, etc.), different production technologies are available (Cieślik et al., 2016; Plugge, 2017; Liu et al., 2017). The basis for technical processes in the scope of agricultural biogas production is provided by biochemical transformations.

\section{Objective, methodology and sources of information}

The main purpose of this study is to analyse the volume of agricultural biogas production in Poland and the structure of consumption of raw materials used for production of agricultural biogas. The analyses were carried out over the period of 2011-2017. The basic source of information was the data obtained from the National Centre for Agricultural Support. In addition, the paper presents results of the research on the agricultural practices as part of the subject area of the development of the agricultural biogas market in Poland. Selected results of a study conducted as part of a project financed from the grant of the National Science Centre (NCN) were presented. The aim of this study was to identify the opportunities for the development of low-carbon production in the Polish agriculture. Empirical research among agricultural producers were conducted over the period from November 2017 to March 2018 using a questionnaire method. The spatial extent of the analyses conducted under the grant covered entire Poland, while the empirical research among farmers was conducted in six randomly selected provinces. The selection was based on a localizational research approach based on territorial units. Six provinces were drawn for the research, one province from each of the macro-regions in Poland. Random selection was also applied to districts in the selected provinces. In each province, 3 districts were drawn and the questionnaire surveys were conducted in these districts. The questionnaire surveys were carried out in cooperation with the Agricultural Advisory Centers based in the 
provinces drawn. The author conducted the surveys among 1101 agricultural holdings in Poland, including:

- 180 farmers in Mazowieckie voivodship;

- 190 farmers in Opolskie voivodship;

- 183 farmers in Lubelskie voivodship;

- 180 farmers in Wielkopolskie voivodship;

- 188 farmers in Małopolskie voivodship;

- 180 farmers in Pomorskie voivodship.

The survey questionnaire concerned many aspects of the low-carbon development, while in this study only a fragment of the research concerning agricultural biogas plants is presented.

\section{Agricultural biogas plants in Poland - location. parameters and raw materials for production}

The first biogas plant in Poland was launched on 9 June 2005 in the town of Pawłówko. As of 1 January 2017, the number of plants entered into the Register ${ }^{3}$ of agricultural biogas producers was 94 (Fig. 1).

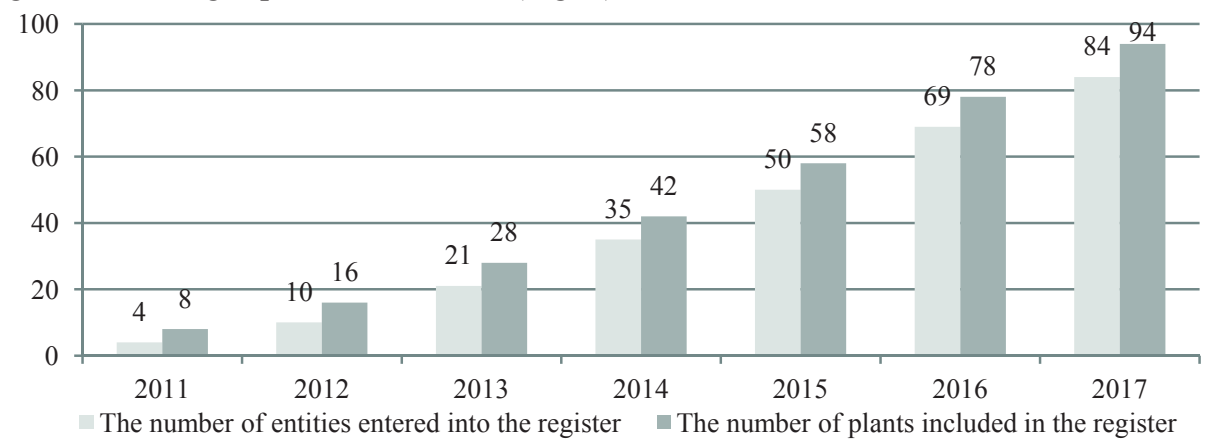

Fig. 1. The number of biogas producers and the number of plants in Poland in the period of 2011-2017

Source: own study based on data obtained from the National Centre for Agricultural Support.

The largest agricultural biogas producer in Poland is Poldanor S.A. company which uses pig liquid manure as the main raw material in its biogas plants. The largest plant for production of agricultural biogas belonging to this company is located in Pomorskie province, in the commune of Koczała (the annual capacity of this plant is $9,200,000 \mathrm{~m}^{3}$ of agricultural biogas) (Piwowar, Dzikuć, 2013; Piwowar, 2014). In the period of 2011-2017, the amount of agricultural biogas produced increased by 255.1 million $\mathrm{m}^{3}$, while the amount of electricity generated from agricultural biogas in this period increased by 534.8 GWh (Fig. 2).

\footnotetext{
${ }^{3}$ Pursuant to Art. 24, paragraph 1 of the Act of 20 February 2015 on renewable energy sources (Journal of Laws: Dz.U. of 2017 , item 1148 , as amended), the authority responsible for keeping the register of agricultural biogas producers is General Director of the National Centre for Agricultural Support. The authority keeping the register of energy companies involved in the production of agricultural biogas was earlier the President of the Agricultural Market Agency.
} 


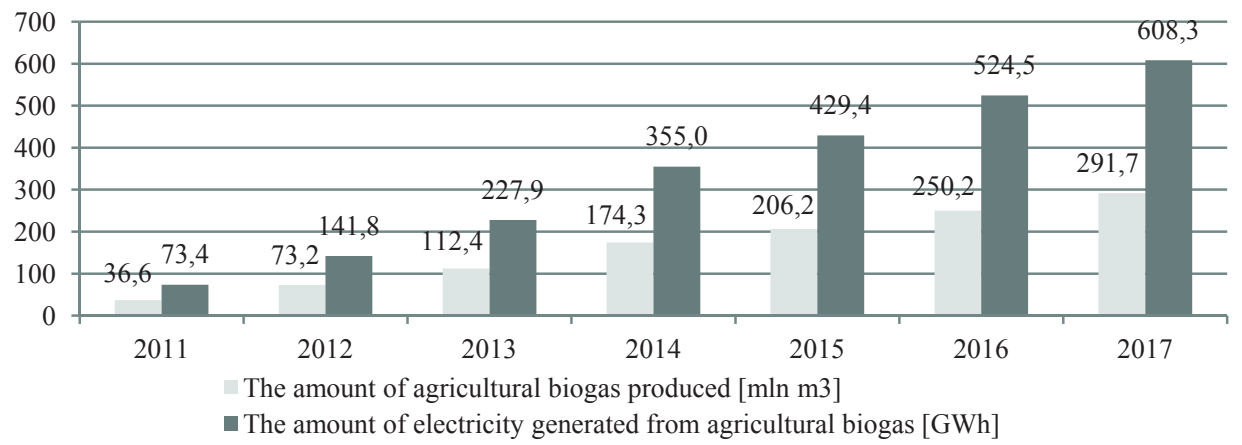

Fig. 2. Production of agricultural biogas and electricity from agricultural biogas in Poland in the period of 2011-2017 Source: own study based on data obtained from the National Centre for Agricultural Support.

As it results from the data presented in Fig. 2, both the amount of agricultural biogas produced and the amount of electricity generated from the agricultural biogas systematically increased during the analyzed period. Very high rates of growth dynamics were observed, the amount of agricultural biogas produced in Poland in 2011-2017 increased almost eight-fold (the rate of dynamics was 796\%), while the amount of energy increased over eight-fold (the rate of dynamics was $828 \%$ ).

As of 31/12/2016, most plants producing agricultural biogas in Poland were located in Zachodniopomorskie province (12 plants), Podlaskie and Warmińsko-Mazurskie provinces (10 plants in each), as well as in Pomorskie, Dolnośląskie and Wielkopolskie provinces (9 plants in each). In terms of the total installed capacity, it is worth noting that in addition to the above mentioned provinces, also plants located in Lubelskie and Kujawsko-Pomorskie provinces are characterized by a relatively high value.

The basic raw material for the production of biogas in agricultural biogas plants in Poland is liquid manure. 266 thousand tons of liquid manure were used for production of biomass in 2011, while 807 thousand tons of this raw material were used for this purpose in 2017. Despite the fact that liquid manure is the most important substrate for production of biogas in agricultural biogas plants in Poland, its share in the structure of the total substrate consumption decreased from $56.7 \%$ in 2011 to $21 \%$ in 2017 . In the period of $2011-2012$, the second most important substrate for production of biogas in agricultural biogas plants was maize silage (108.9 thousand tones and 241.6 thousand tones were consumed respectively, which accounted for $23.2 \%$ and $26.3 \%$ in the structure of consumption). It is worth noting that in the last of the analyzed years, a high consumption of maize silage (472.2 thousand tones) did not translate into a high share in the structure of consumption (it was only $12.4 \%$ ). In the analyzed period, there took place a distinct increase in the volume of raw materials, such as fruit and vegetable residues, distillers grains with solubles and beet pulp, as well as in their share in the consumption structure. Other raw materials are also used more and more frequently (the share of the category "other" in the structure of consumption in 2017 was $18.9 \%$ ). They include, inter alia, process sludge from agricultural and food industry as well as waste from dairy industry. The literature of the subject often emphasizes advantages of the use of the methane digestion process for purposes of rational management of production waste from the food industry, including from dairy and distillers companies (Michalska, Pazera, Bizukojć, 2013; Jasiulewicz, 2017) and fruit \& vegetable 
processing plants (Szwarc et al., 2015). However it is worth emphasizing that sources of substrates for production of agricultural biogas can also be sought in other branches of the food industry, including meat industry.

\section{Prospects for the development of the agricultural biogas market - results of empirical studies}

As mentioned above, one of the topics undertaken in empirical studies were agricultural practices as part of the management of raw materials and waste from crop production for non-food purposes. A relatively large percentage of the respondents $(35.8 \%)$ indicated that the aim of the activities performed as part of crop production is also cultivation of plants for energy purposes. Declarations of the respondents in this matter in the spatial arrangement of research are presented in Table 1.

Table 1. Declarations of respondents regarding the use of biomass from field crops and grasslands for energy purposes

\begin{tabular}{|c|c|c|c|c|}
\hline Specification & Yes & No & $\begin{array}{l}\text { I do not know } \\
{[\%]}\end{array}$ & Non-response \\
\hline Lubelskie voivodship & 41.5 & 49.2 & 6.6 & 2.7 \\
\hline bialski district & 55.0 & 41.7 & 1.7 & 1.7 \\
\hline lubartowski district & 46.8 & 53.2 & 0.0 & 0.0 \\
\hline zamojski district & 23.0 & 52.5 & 18.0 & 6.6 \\
\hline Małopolskie voivodship & 20.2 & 61.7 & 11.7 & 6.4 \\
\hline gorlicki district & 4.4 & 83.8 & 2.9 & 8.8 \\
\hline proszowicki district & 30.0 & 53.3 & 15.0 & 1.7 \\
\hline tarnowski district & 28.3 & 45.0 & 18.3 & 8.3 \\
\hline Mazowieckie voivodship & 27.8 & 56.7 & 11.7 & 3.9 \\
\hline łosicki district & 18.3 & 60.0 & 15.0 & 6.7 \\
\hline makowski district & 46.7 & 41.7 & 10.0 & 1.7 \\
\hline żuromiński district & 18.3 & 68.3 & 10.0 & 3.3 \\
\hline Opolskie voivodship & 42.6 & 40.0 & 15.3 & 2.1 \\
\hline kluczborski district & 41.0 & 44.3 & 13.1 & 1.6 \\
\hline oleski district & 52.2 & 36.2 & 8.7 & 2.9 \\
\hline opolski district & 33.3 & 40.0 & 25.0 & 1.7 \\
\hline Pomorskie voivodship & 40.0 & 43.9 & 11.7 & 4.4 \\
\hline gdański district & 55.0 & 30.0 & 6.7 & 8.3 \\
\hline kartuski district & 11.7 & 60.0 & 28.3 & 0.0 \\
\hline sztumski district & 53.3 & 41.7 & 0.0 & 5.0 \\
\hline Wielkopolskie voivodship & 42.8 & 35.0 & 18.9 & 3.3 \\
\hline gnieźnieński district & 50.0 & 33.3 & 8.3 & 8.3 \\
\hline koniński district & 35.0 & 45.0 & 20.0 & 0.0 \\
\hline międzychodzki district & 43.3 & 26.7 & 28.3 & 1.7 \\
\hline Total & 35.8 & 47.8 & 12.6 & 3.8 \\
\hline
\end{tabular}

Source: own study based on questionnaire surveys. 
According to the analyses, a high percentage of farmers declaring production of raw materials for energy purposes was recorded in Wielkopolskie, Opolskie, Lubelskie and Pomorskie provinces. For example, in Bialski district (Lubelskie province), half of the surveyed farmers indicated that they allocated raw materials from field production and permanent grasslands for this purpose. It is worth noting that some agricultural biogas plants are operated in this district as well as in districts bordering with it (e.g. Parczewski district). In turn, a low percentage of positive responses in this subject area was recorded among farmers in Małopolskie province (especially in Gorlicki district) and in Mazowieckie province (except for Makowski district). It is interesting that there was a high percentage of farmers declaring a lack of knowledge in the investigated subject area. This may be associated with a lack of knowledge about the final use of the products sold, e.g. straw. Agricultural producers also indicated groups of plants ${ }^{4}$, the vegetative elements of which were used for energy purposes (fig. 3).

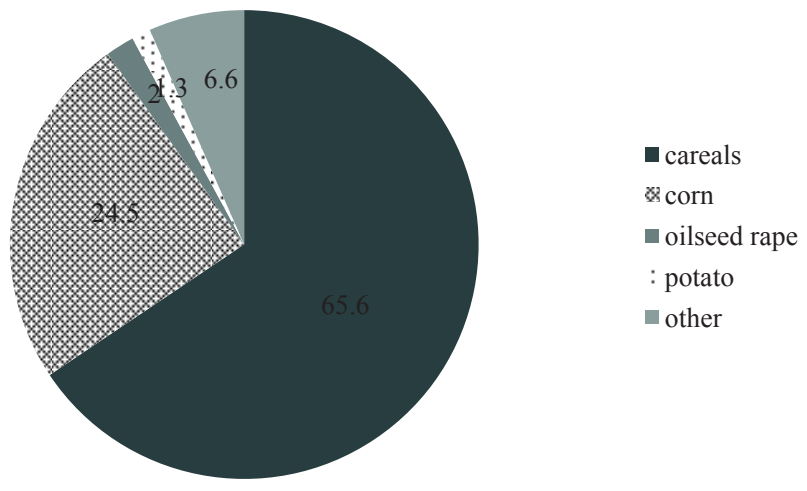

Fig. 3. Plant groups intended for energy purposes in the surveyed agricultural holdings

Source: own study based on questionnaire surveys.

The basic plants used for energy purposes in the surveyed agricultural holdings were cereals. In this group, the respondents indicate post-harvest residues. The energy potential of straw was indicated by farmers cultivating wheat, barley, triticale and rye. Waste agricultural biomass in the form of poor quality hay is also used as feedstock in agricultural biogas plants. In addition, some farmers indicated rye (whole-crop silage and grain meal) as substrate for biogas production (especially in Wielkopolskie and Opole provinces). Maize is also among plants extremely important in this subject area. Maize silage and straw are particularly important for purposes of production of agricultural biogas. A small percentage of farmers indicated rape ( $2 \%$ of respondents) and potatoes ( $1.3 \%$ of respondents). In turn, $6.6 \%$ of respondents indicated other plants (including grasses from field crops, papilionaceous plants and their mixtures with grasses, lichen from grasslands, and sugar beets).

Agricultural biogas in Poland is produced on a relatively small scale in relation to the conditions and possibilities of obtaining raw materials. The low degree of utilization of the opportunities to produce agricultural biogas results, inter alia, from a low efficiency of the system for supporting this activity at the level of agricultural holdings. The profitability can be improved not only through investment support at the stage of implementing a project of

\footnotetext{
${ }^{4}$ Farmers answered the questions concerning, inter alia, the management of waste from crop production.
} 


\section{A. Piwowar}

building and commissioning a production plant, but also through higher sales prices of energy. Agricultural biogas plants, in particular micro-plants, are characterized currently by a low profitability (Gołasa, 2014; Sulewski et al., 2016).

Lignocellulosic plants are essential for the development of the plant-based biofuel market. In the questionnaire there was a question whether in favorable price conditions the farmer would like to cultivate energy crops (such as energy willow and Virginia mallow) for the needs of biomass-fired boilers or biogas plants. Answers to this question are presented in Table 2.

Table 2. Declarations of the respondents regarding the willingness to cultivate energy crops in favorable economic conditions

\begin{tabular}{|c|c|c|c|c|}
\hline Specification & Yes & No & $\begin{array}{l}\text { I do not know } \\
\%]\end{array}$ & Non-response \\
\hline Lubelskie voivodship & 14.8 & 78.1 & 5.5 & 1.6 \\
\hline bialski district & 13.3 & 78.3 & 5.0 & 3.3 \\
\hline lubartowski district & 19.4 & 80.6 & 0.0 & 0.0 \\
\hline zamojski district & 11.5 & 75.4 & 11.5 & 1.6 \\
\hline Małopolskie voivodship & 7.4 & 78.7 & 7.4 & 6.4 \\
\hline gorlicki district & 4.4 & 85.3 & 1.5 & 8.8 \\
\hline proszowicki district & 8.3 & 81.7 & 6.7 & 3.3 \\
\hline tarnowski district & 10.0 & 68.3 & 15.0 & 6.7 \\
\hline Mazowieckie voivodship & 8.3 & 83.3 & 6.7 & 1.7 \\
\hline łosicki district & 10.0 & 83.3 & 3.3 & 3.3 \\
\hline makowski district & 3.3 & 85.0 & 10.0 & 1.7 \\
\hline żuromiński district & 11.7 & 81.7 & 6.7 & 0.0 \\
\hline Opolskie voivodship & 3.7 & 85.8 & 10.5 & 0.0 \\
\hline kluczborski district & 4.9 & 78.7 & 16.4 & 0.0 \\
\hline oleski district & 0.0 & 89.9 & 10.1 & 0.0 \\
\hline opolski district & 6.7 & 88.3 & 5.0 & 0.0 \\
\hline Pomorskie voivodship & 8.3 & 76.7 & 13.9 & 1.1 \\
\hline gdański district & 3.3 & 88.3 & 5.0 & 3.3 \\
\hline kartuski district & 6.7 & 63.3 & 30.0 & 0.0 \\
\hline sztumski district & 15.0 & 78.3 & 6.7 & 0.0 \\
\hline Wielkopolskie voivodship & 14.4 & 74.4 & 10.6 & 0.6 \\
\hline gnieźnieński district & 10.0 & 80.0 & 10.0 & 0.0 \\
\hline koniński district & 23.3 & 71.7 & 5.0 & 0.0 \\
\hline międzychodzki district & 10.0 & 71.7 & 16.7 & 1.7 \\
\hline Total & 9.4 & 79.6 & 9.1 & 1.9 \\
\hline
\end{tabular}

Source: own study based on questionnaire surveys.

As it appears from the analyses, farmers declared a low level of interest in cultivation of energy crops - even in favorable economic conditions. In total, 9.4\% of the respondents declared that they wanted to grow such plants. In the spatial arrangement of research, the highest percentage of positive responses was recorded in Lubelskie province $(14.8 \%$ of respondents) and in Wielkopolskie province (14.4\% of respondents). For comparison, in Opolskie province, only $3.7 \%$ of the respondents declared their interest in cultivation of energy crops in favorable economic conditions. 


\section{Summary}

Agricultural biogas plants constitute an area of special importance in the agribusiness. In this area, alternative production is combined with a possibility of additional income for farmers and limitation of the negative impact on the natural environment. Agricultural biogas plants can be treated as an important form of progress in the agribusiness. Continuation of the technological and technical evolution based on a closed cycle of the circulation of organic components. Agricultural biogas plants help reducing the emissions of greenhouse gases generated by agriculture and the agri-food industry. Despite the development of the market of agricultural biogas plants in Poland in the period of 20112017 , the number of plants producing agricultural biogas and the scale of their operation are still relatively low as compared with the production potential. However it is worth emphasizing that in the structure of consumption of substrates for production of agricultural biogas in Poland there is a significant increase in the share of residues from the industrial processing of agricultural raw materials in the agri-food industry. An analysis of the secondary data and the questionnaire survey data showed that the agricultural biogas market in Poland was strongly differentiated between regions, both in terms of the number of plants and raw materials used for production.

Agricultural activity, like any other economic activity, may have a negative impact on the environment. From the viewpoint of the development of low-carbon agricultural economy it is important to reduce this adverse impact and to minimize undesirable effects. Greenhouse gas emissions are among the most serious environmental threats resulting from the agricultural activity. One of main problems in the aspect of environmental protection is intensive animal production which results in generation of large amounts of feces, while the possibilities of their "green" utilization are limited. In view of the above, the development of agricultural biogas plants, in which the feedstock (e.g. liquid manure) is transformed into bioenergy, is of particular importance. The biomass from field crops and grasslands can also be used in agricultural biogas plants. The questionnaire surveys show that the highest percentage of farmers declaring the allocation of plant feedstock for the needs of agricultural biogas plants was in Wielkopolskie, Opolskie, Lubelskie and Pomorskie provinces. At the same time, the number of farmers interested in cultivation of energy crops, even in economic conditions favorable for this type of crop production, was low. This may result from the need to purchase appropriated technical equipment for the cultivation and nurturing, as well as from the problems in the scope of the biomass transport and storage logistics. Knowledge about energy crops technology is also necessary, which causes an increase in the educational needs of farmers in this subject area.

\section{Acknowledgements}

This study was conducted and financed in the framework of the research project "The state and prospects of the development of low-carbon agriculture in Poland and the behaviour of agricultural producers", granted by the National Science Centre in Poland. Program SONATA, grant No. 2016/21/D/HS4/00087. 


\section{References}

Appel, F., Ostermeyer-Wiethaup, A., Balmann, A. (2016). Effects of the German Renewable Energy Act on structural change in agriculture - The case of biogas. Utilities Policy, 41, 172-182.

Bała, D. (2017). Możliwości integracji producentów rolnych w oparciu o substrat energetyczny w województwie wielkopolskim (Opportunities for integrating agricultural producers based on energy substrate in the Wielkopolskie Voivodship). Rozwój Regionalny i Polityka Regionalna, 40, 215-225.

Chodkowska-Miszczuk, J., Kulla, M., Novotný, L. (2017). The role of energy policy in agricultural biogas energy production in Visegrad countries. Bulletin of Geography. Socio-economic Series, 35(35), 19-34.

Cieślik, M., Dach, J., Lewicki, A., Smurzyńska, A., Janczak, D., Pawlicka-Kaczorowska, J., Boniecki, P., Cypik, P., Czekała, W., Jóźwiakowski, K. (2016). Methane fermentation of the maize straw silage under meso-and thermophilic conditions. Energy, 115, 1495-1502.

Czekała, W. (2018). Agricultural Biogas Plants as a Chance for the Development of the Agri-Food Sector. Journal of Ecological Engineering, 19, 2.

D'Imporzano, G., Pilu, R., Corno, L., Adani, F. (2018). Arundo donax L. can substitute traditional energy crops for more efficient, environmentally-friendly production of biogas: A Life Cycle Assessment approach. Bioresource Technology, 267, 249-256.

European Parliament (2009). Directive 2009/28/EC of the European Parliament and of the Council of 23 April 2009. Off J. Eur. Union, 140,16-62.

Gołasa, P. (2014). Gospodarstwa rolne jako producenci substratów do produkcji biogazu rolniczego (Farms as producers of substrates for the production of agricultural biogas energy). Roczniki Naukowe Stowarzyszenia Ekonomistów Rolnictwa i Agrobiznesu, 16(6), 132-136.

Ingrao, C., Bacenetti, J., Adamczyk, J., Ferrante, V., Messineo, A., \& Huisingh, D. (2019). Investigating energy and environmental issues of agro-biogas derived energy systems: A comprehensive review of Life Cycle Assessments. Renewable Energy, 136, 296-307.

Jasiulewicz, M. (2017). Wdrożenie innowacyjnej inwestycji pilotażowej w przemyśle przetwórstwa spożywczego oraz w biogazowni w zakresie bioenergetyki (Inplementation of the innovative investment in food industry and anaerobic digestion in the field of bioenergy). Roczniki Naukowe Stowarzyszenia Ekonomistów Rolnictwa i Agrobiznesu, 19(2), 89-94.

Kozłowski, K., Dach, J., Lewicki, A., Cieślik, M., Czekała, W., Janczak, D., \& Brzoski, M. (2018). Laboratory Simulation of an Agricultural Biogas Plant Start-up. Chemical Engineering \& Technology, 41(4), 711-716.

Kuziemska, B., Trębicka, J., Wieremiej, W., Klej, P., Pieniak-Lendzion, K. (2014). Korzyści i zagrożenia w procesie produkcji biogazu (Benefits and risks in the production of biogas). Zeszyty Naukowe Uniwersytetu Przyrodniczo-Humanistycznego w Siedlcach. Administracja i Zarzadzanie, 30 (103), 99-113.

Liu, T., Sun, L., Müller, B., Schnürer, A. (2017). Importance of inoculum source and initial community structure for biogas production from agricultural substrates. Bioresource Technology, 245, 768-777.

Majewski, E., Sulewski, P., Was, A. (2016). Potencjał i uwarunkowania produkcji biogazu rolniczego w Polsce (Potentialand conditions of agricultural biogas production in Poland). Warszawa: Wydawnictwo SGGW.

Michalska, K., Pazera, A., Bizukojć, M. (2013). Innowacje dla branży mleczarskiej - biogazownie przyzakładowe (Innovations for the dairy industry - biogas compounds). Acta Innovations, 9.

Piwowar A., Olszańska A., Režný L. (2017). Development of renewable energy in the Visegrad countries comparative analysis. Univerzita Hradec Kralove, Hradecke Ekonomicke Dny 2017, Gaudeamus Hradec Kralove, 696-705.

Piwowar, A. (2014). Biogazownie rolnicze w Polsce - lokalizacja i parametry techniczne instalacji (Agricultural biogas plants in Poland location and technical characteristics of this infrastructure). Technika Rolnicza Ogrodnicza Leśna, 6, 7-9.

Piwowar, A., Dzikuć, M. (2013). Charakterystyka podmiotów zajmujących się wytwarzaniem biogazu rolniczego w Polsce (Characteristics of agricultural biogas manufacturers in Poland). Journal of Agribusiness and Rural Development, 1, 207-217.

Piwowar, A., Dzikuć, M., Adamczyk, J. (2016). Agricultural biogas plants in Poland-selected technological, market and environmental aspects. Renewable and Sustainable Energy Reviews, 58, 69-74.

Plugge, C.M. (2017). Biogas. Microbial Biotechnology, 10(5), 1128-1130.

Scarlat, N., Dallemand, J.F., Fahl, F. (2018). Biogas: Developments and perspectives in Europe. Renewable Energy, 129, 457-472.

Sulewski, P., Majewski, E., Wąs, A., Szymańska, M., Malak-Rawlikowska, A., Fraj, A., Trząski A., Wiszniewski A., Amrozy, M. (2016). Uwarunkowania ekonomiczno-prawne i opłacalność inwestycji w biogazownie rolnicze w Polsce (Economic and legal condition and profitability of investments for agricultural biogas plants in Poland). Zagadnienia Ekonomiki Rolnej, 1, 119-143. 
Szwarc, M., Kupczyk, A., Zubrzycki, M., Sikora, M., Trajer, J. (2015). Biogazownie-sukcesy i porażki (Biogas plants - successes and failures). Przemyst Fermentacyjny i Owocowo-Warzywny, 5(59), 27-29.

Torrijos, M. (2016). State of development of biogas production in Europe. Procedia Environmental Sciences, 35, 881-889.

Zain, M.M., Mohamed, A.R. (2018). An overview on conversion technologies to produce value added products from $\mathrm{CH} 4$ and $\mathrm{CO} 2$ as major biogas constituents. Renewable and Sustainable Energy Reviews, 98, 56-63.

\section{For citation:}

Piwowar A. (2019). Development of the Agricultural Biogas Market in Poland - Production Volume, Feedstocks, Activities and Behaviours of Farmers. Problems of World Agriculture, 19(1),88-97; DOI: $10.22630 /$ PRS.2019.19.1.8 